\title{
Detailed mapping of a congenital heart disease gene in chromosome $3 \mathrm{p} 25$
} Elaine K Green, Matthew D Priestley, Jonathan Waters, Chris Maliszewska, Farida Latif,
Eamonn R Maher analysis of large AVSD families have excluded linkage to the Down syndrome critical region on chromosome 21, so establishing locus heterogeneity in the genetic pathogenesis of AVSD. ${ }^{23}$ In view of the complexity of cardiac development, such heterogeneity is expected. Linkage analysis in a large extended family mapped an atrioventricular septal defect susceptibility locus to chromosome $1 \mathrm{p} 31-\mathrm{p} 21 .^{4}$ In this kindred inheritance was observed to be autosomal dominant with incomplete penetrance. However, large AVSD families are rare, and so the potential for identifying AVSD genes using linkage is limited.

Cytogenetic deletion syndromes are rare, but can provide important clues to the localisation of developmental genes. Classical examples of this approach include the association of cardiac and other developmental defects with chromosome 22q11 deletions, and the occurrence of Hirschsprung disease (HSCR) with chromosome 10 deletions, leading to the identification of RET as a HSCR susceptibility gene. Cytogenetic deletion syndromes associated with AVSD include $\operatorname{del}(8)(\mathrm{p} 23)^{56}$ and $\operatorname{del}(3)(\mathrm{p} 25) .^{7}$ Analysis of $\operatorname{del}(8)(\mathrm{p} 23)$ cases mapped the critical deletion region for heart defects and microcephaly to a 6 $\mathrm{Mb}$ region of $8 \mathrm{p} 23.1 .^{8}$ Distal deletion of the short arm of chromosome 3 ( $3 p-$ syndrome) is a rare disorder ( $\sim 25$ reported cases) associated with developmental and growth retardation as well as a characteristic dysmorphology (including ptosis, telecanthus, and micrognathia). Additional, but variable, developmental defects include postaxial polydactyly, renal anomalies, cleft palate, and gastrointestinal anomalies. Congenital heart defects occur in about a third of patients ${ }^{79}$ and are typically AVSDs. To date, all patients with $3 \mathrm{p}-$ syndrome have had large cytogenetically visible deletions, although there are also reports of patients with large deletions and a normal phenotype ${ }^{10}$ (unpublished observations).

We and others have reported that the extent of distal $3 p$ deletions in $3 p-$ syndrome patients is variable. ${ }^{79}$ Furthermore, we found that of five patients with $3 p-$ syndrome studied, the three with CHD had the most proximal breakpoints. Subsequently, Drumheller et $a l^{11}$ reported data on five patients (including one case studied previously by us ${ }^{7}$ ) that provided further evidence for a chromosome 3p25 CHD gene. To confirm and extend these findings we have collected a total of 10 cases of $3 p-$ syndrome and performed molecular cytogenetic and molecular genetic studies to define the extent of the $3 p$ deletions and correlate this with the presence or absence of CHD. 
Table 1 Details of FISH probes and microsatellite markers used in the study. The probes marked by * are PAC clones derived from RPCI1 library, and those probes starting with $A C$ are cosmid probes isolated from the library LLO3NCO1, both obtained from the UK HGMP resource centre

\begin{tabular}{|c|c|c|}
\hline Locus & FISH probe & Polymorphism \\
\hline D3S1304 & - & Microsatellite \\
\hline D3S18 & cLIB 1 & - \\
\hline D3S1597 & - & Microsatellite \\
\hline D3S1317 & - & Microsatellite \\
\hline D3S601 & $\cos 7$ & - \\
\hline D3S1038 & $\cos 14$ & Microsatellite \\
\hline D3S3589 & $61 \mathrm{P} 20^{\star} / \mathrm{AC} 50 \mathrm{~K} 12$ & Microsatellite \\
\hline D3S587 & CLIB $12-48$ & - \\
\hline D3S3601 & - & Microsatellite \\
\hline D3S3594 & 226D20 & Microsatellite \\
\hline D3S1263 & $283 \mathrm{~J} 16^{\star}$ & Microsatellite \\
\hline NIB1677 & $201 \mathrm{I} 11^{\star}$ & Microsatellite \\
\hline D3S3714 & $183 \mathrm{M} 12^{\star} / \mathrm{AC} 12 \mathrm{~J} 24, \mathrm{AC} 19 \mathrm{C} 22$ & Microsatellite \\
\hline D3S3680 & $183 \mathrm{M} 12^{\star}$ & Microsatellite \\
\hline D3S3088 & $225 \mathrm{~B} 20^{\star} / \mathrm{AC} 38 \mathrm{~A} 7$ & - \\
\hline D3S1259 & $248 \mathrm{M} 7 \star / 275 \mathrm{~B} 20^{\star}$ & Microsatellite \\
\hline D3S3701 & - & Microsatellite \\
\hline D3S3602 & - & Microsatellite \\
\hline D3S3693 & - & Microsatellite \\
\hline D3S3610 & - & Microsatellite \\
\hline D3S1585 & 289I19* & Microsatellite \\
\hline
\end{tabular}

\section{Materials and methods}

PATIENTS AND SAMPLES

Lymphoblastoid cell lines were available for nine patients: P1, P2 (CUMG3.1), P3 (GM 10922), P4, P5 (CUMG3.4), P6, P7, P8 (GM 10985), and P9, but not P10 (CUMG3.10). DNA was collected from the affected child and both parents in seven families (P1, P2, P5, P6, P7, P9, and P10), from the affected child and mother in one case (P4), and only the affected child for P3 (GM 10922) and P8 (GM 10995).

P1 ARTIFICIAL CHROMOSOME (PAC) ISOLATION AND MAINTENANCE

P1 clones were isolated by PCR based screening using polymorphic marker primers ( $3 \mathrm{p} 25-$ 26) from the UK HGMP resource centre RPCI1 library. ${ }^{12} \mathrm{P} 1$ clones were maintained in LB media supplemented with $25 \mu \mathrm{g} / \mathrm{ml}$ Kanamycin and PAC DNA was isolated from the host strains by column purification using the Qiagen Maxi kit (Qiagen). The manufacturer's recommended protocol adaptations for opti- mal recovery of PAC DNA were used. The P1 clones isolated are shown in table 1.

ISOLATION OF COSMIDS

Cosmids were isolated for the markers D3S3088, D3S3714, and D3S3589 from the chromosome 3 library LLO3NO3 obtained from the UK HGMP resource centre. Hybridisation probes were prepared from the amplified PCR products from YAC 753F7 and 70D6 DNA, purified by Qiagen PCR product kit and radiolabelled by random priming $\sim 25 \mathrm{ng}$ using the Rediprime kit (Amersham). Repetitive sequences were blocked by preannealing with Cot-1 DNA (Gibco BRL) and hybridising under standard conditions $s^{12}$ at $65^{\circ} \mathrm{C}$. The identified clones (table 1) were obtained from the UK HGMP resource centre then maintained in LB media supplemented with ampicillin. Cosmid DNA was isolated using the Qiagen Midi kit.

FLUORESCENCE IN SITU HYBRIDISATION (FISH)

Metaphase chromosome spreads were prepared from EBV transformed cell lines using standard methods. Before chromosome harvest, cells were blocked in metaphase by the addition of colcemid to a concentration of 10 $\mu \mathrm{g} / \mathrm{ml}$. Probes (PACs, cosmids, and YACs) were biotinylated by nick translation with biotin-11dUTP (Bionick labelling system, Gibco BRL). Chromosomal in situ suppression (CISS) hybridisation was performed to improve the specificity of the hybridisation, with Cot-1 DNA (Gibco BRL) added to the biotin labelled probe at a ratio of 50:1. For all hybridisations, a biotin labelled chromosome 3 alpha satellite centromere probe (Oncor) was used as a control to identify chromosome 3.

Hybridisation signals were visualised by a three layer avidin-fluorescein isothiocyanate (FITC), biotinylate anti-avidin detection system. Analysis was carried out using a BX50 Olympus microscope and images captured with an automated image analysis system (Cytovision, Applied Imaging). At least 20 metaphases were analysed for each probe.

Table $2 \quad 3 p$-deletion mapping results

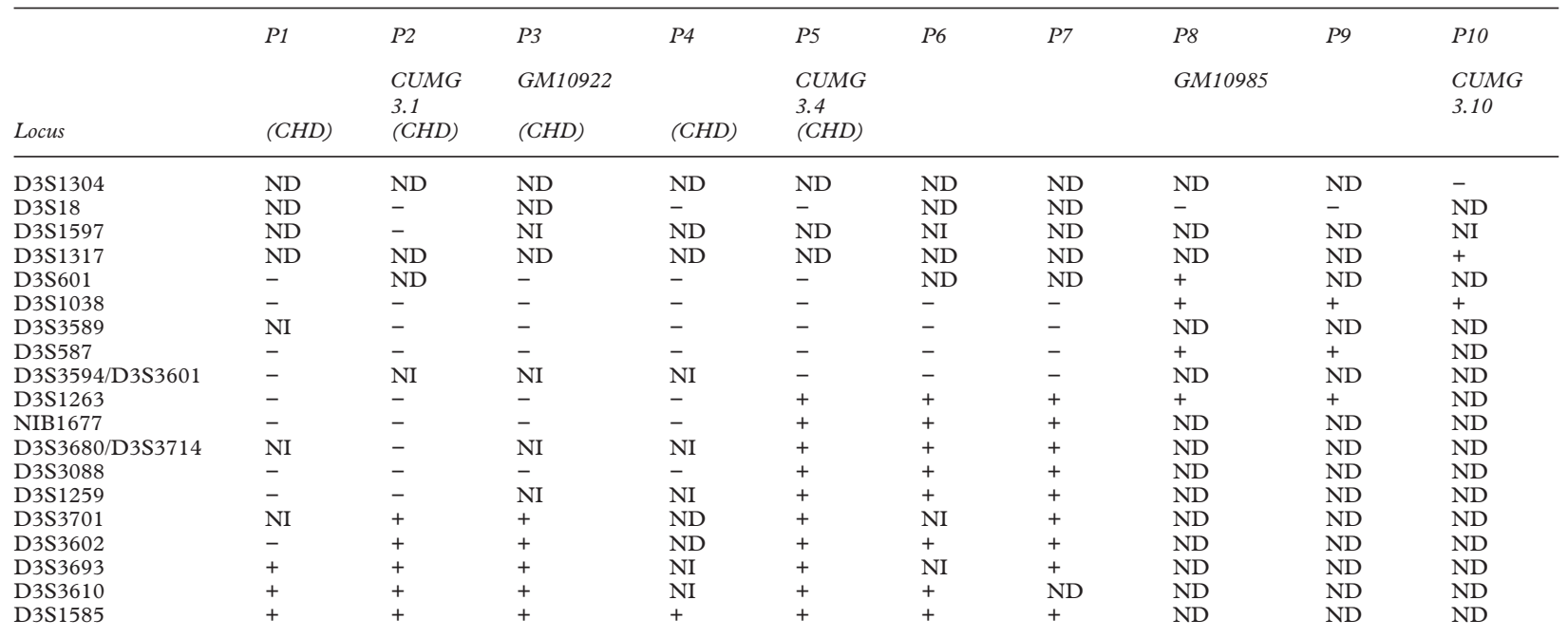

$+=$ locus retained. $-=$ locus deleted. $\mathrm{NI}=$ non-informative. $\mathrm{ND}=$ not done. 
DIRECT DNA SEQUENCING OF PACS

The ends of the PACs were directly sequenced by automated fluorescence chain termination sequencing. At least $2 \mu \mathrm{g}$ of PAC DNA was required for the sequencing reaction, with 25 pmol vector primer (T7 or Sp6), $8 \mu 1$ di-rhodamine kit reaction mix (Applied Biosystems) to a final volume of $20 \mu \mathrm{l}$, overlaid with mineral oil, and thermal cycled under the following conditions: $98^{\circ} \mathrm{C}$ for 20 seconds, $50^{\circ} \mathrm{C}$ for 20 seconds, and $60^{\circ} \mathrm{C}$ for four minutes for 35 cycles on a Omn-E thermal cycler (Hybaid). Samples were precipitated, washed, and resuspended in denaturing buffer
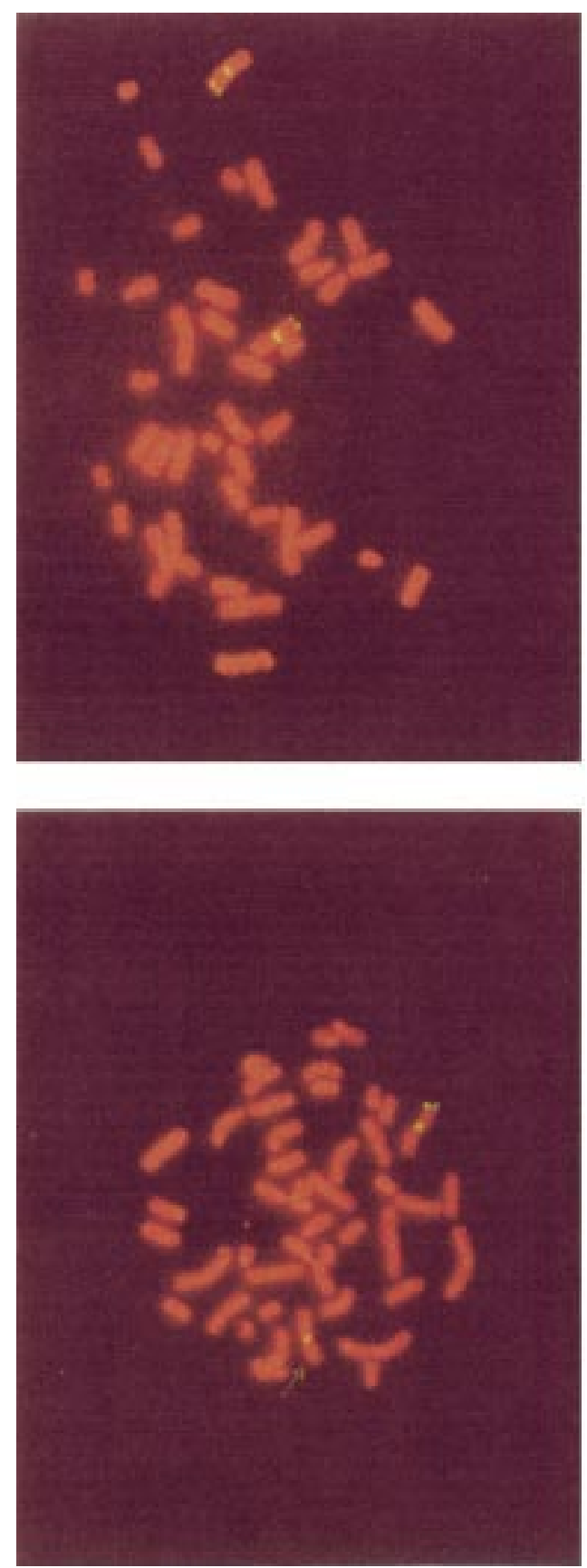

Figure 1 FISH mapping studies. (Top left) P5 hybridised with PAC 283716 for D12S1263 and centromeric probe

D3Z1. Both chromosome 3 homologues are identified with both probes. (Bottom left) P5 hybridised with PAC 226D20 for D3S3594 and D3Z1. Both chromosome 3 homologues were identified by D3Z1, but only one homologue by PAC $226 D 20$. (Top right) P6 hybridised with PAC 283716 for D12S1263 and centromeric probe D3Z1. Both chromosome 3 homologues are identified with both probes. (Bottom right) P6 hybridised with PAC 226D20 for D3S3594 and D3Z1. Both chromosome 3 homologues were identified by D3Z1, but only one homologue by PAC 226D20. AND MAINTENANCE

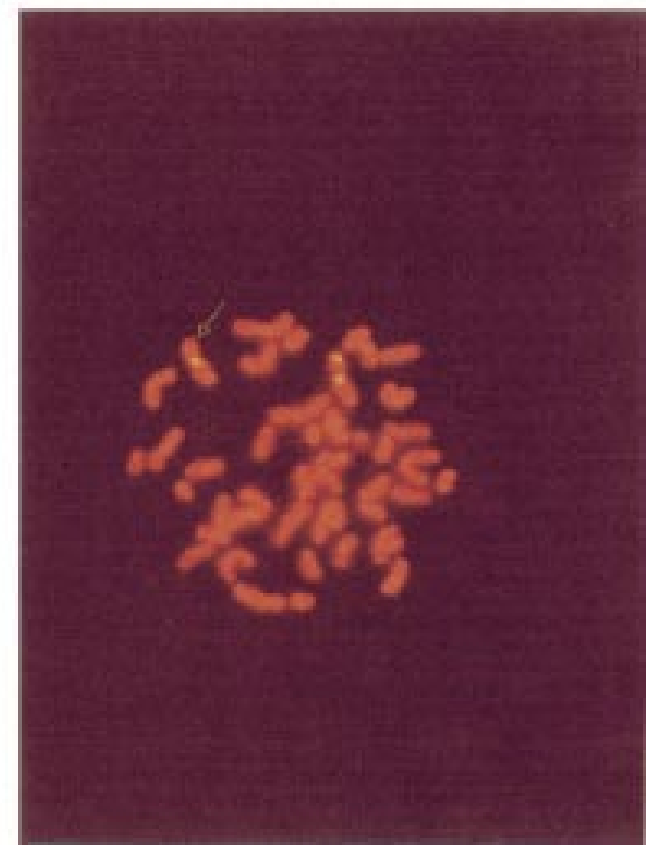

before denaturing and loading onto the ABI 377 sequencer according to the manufacturer's instructions (Applied Biosystems).

YEAST ARTIFICIAL CHROMOSOME (YAC) ISOLATION

YACs were obtained from the UK HGMP resource centre. YAC DNA was isolated following a 36 hour culture in YEPD media, using a analysis was performed using YAC DNA to confirm that the YACs were not chimeric. Overlaps between YACs were confirmed by PCR

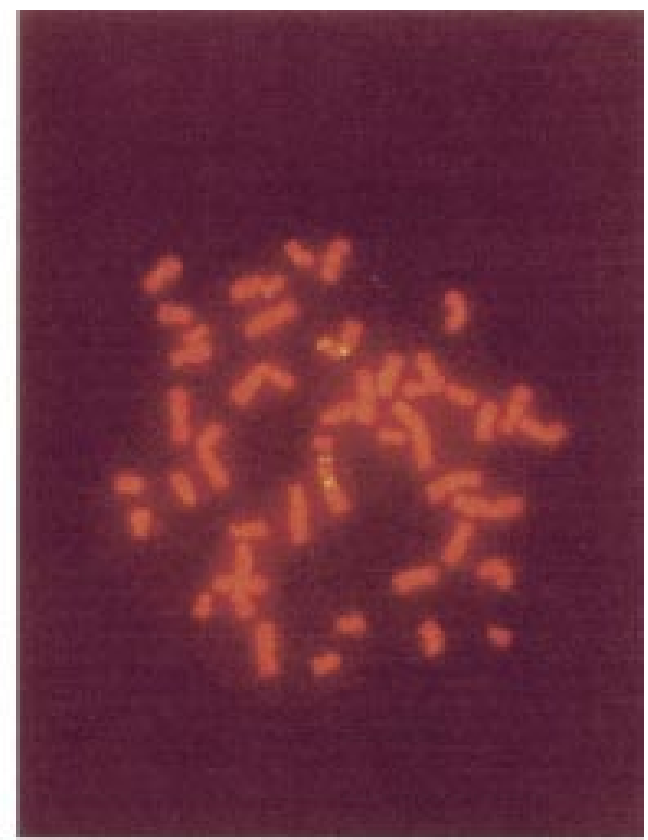

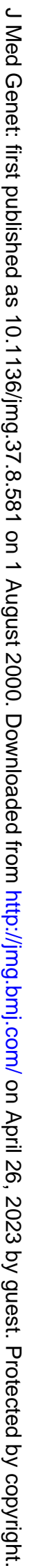


using primers for the polymorphic and STS markers positioned on each of the YACs.

POLYMORPHIC MARKER ANALYSIS

Dinucleotide polymorphic microsatellite markers (table 1) from chromosome 3p25-26 were analysed on the patients and (when available) their parents. Markers were identified through the Genome Database (GDB) and CEPH. A standard PCR was performed using the forward primer 5' end labelled with $\gamma^{32} \mathrm{P}$ ATP and thermal cycled on an Omn-E thermal cycler (Hybaid). The PCR products were separated in a $6 \%$ denaturing polyacrylamide gel and subjected to autoradiography. To establish whether a polymorphic locus was deleted, patient alleles were compared to parental allelotype. For those patients for whom neither or only one parental DNA sample was available (P3 (GM10922), P8 (GM10985), and P4), heterozygosity for a marker was indicative of absence of a deletion.

GENE MAPPING ON CHROMOSOME 3p25

Genes known to map to 3p25 were precisely positioned by PCR amplification using gene specific primers on available YACs and PACs. PCR primers were designed for either the 5'UTR of gene sequence, as for KIAA0121, or the 3'UTR, as for TIMP4 (tissue inhibitor of metalloproteinases 4) and Sec13R. The STS WI6061 in ATP2B2 (plasma membrane calcium transporter gene) was amplified, as was an intragenic dinucleotide repeat polymorphism in fibulin $2 .{ }^{14}$

VECTORETTE PCR AND DNA SEQUENCING OF YAC CLONE INSERT ENDS

Vectorette PCR was used to facilitate sequencing of YAC insert ends. YAC DNA was digested with either EcoRV or RsaI restriction enzyme and ligated to the vectorette. ${ }^{15}$ A nested PCR amplification was performed using the vectorette primer and YAC vector primers. ${ }^{15}$ Vectorette PCR products were gel purified using the Qiagen Gel Extraction kit and were sequenced directly on an ABI 377 semiautomated sequencer using standard methods.

\section{Results}

CLINICAL STUDIES

In addition to the five cases described previously, ${ }^{7}$ five new patients (P1, P4, P6, P7, and P9) were ascertained. All patients had mental retardation and classical dysmorphological features of $3 p-$ syndrome. A total of five cases (three reported previously) had evidence of congenital heart disease (P1, P2, P3, P4, and P5).

CHROMOSOME 3p DELETION MAPPING: INITIAL EVALUATION

In order to confirm the cytogenetic diagnosis, FISH studies and microsatellite marker analyses were performed. The latter method was also used to determine the parent of origin in the six informative cases (table 1). Analysis at up to 21 loci showed that seven cases had deletion breakpoints extending centromeric to D3S3594 (table 2). The three cases with more distal breakpoints (P8 (GM10985), P9, and
P10 (CUMG3.10)) did not have CHD. The deletion breakpoint for P8 (GM 10985) was previously mapped to between D3S601 and D3S18. ${ }^{7}$ Patient P10 (CUMG3.10) had been shown to have a $3 \mathrm{p}$ deletion by cytogenetic analysis and had classical phenotypic features of $3 p-$ syndrome, although previous molecular analysis had not detected a chromosome $3 \mathrm{p}$ deletion. ${ }^{7}$ We have now shown the breakpoint interval for P10 (CUMG3.10) to be between D3S1317 and D3S1304. In P9 the breakpoint was shown to be telomeric to D3S1038.

CHROMOSOME 3p DELETION MAPPING: DETAILED ANALYSIS OF THE CHD CANDIDATE REGION The seven patients with the most centromeric deletion breakpoints were analysed in detail, including three of the cases reported previously (P2 (CUMG3.1), P3 (GM10922), and P5 (CUMG3.4)). Congenital heart disease was present in five of the seven patients. A total of 16 loci from D3S1585 to D3S1038 were analysed (tables 1 and 2, figs 1 and 2). The four patients with the most extensive deletions (P1, P2, P3, and P4), with deletion breakpoints between D3S3693 and D3S1263, all had CHD. A further three patients, one with CHD and two without (P5 (CUMG3.4), P6, and P7), had deletion breakpoints distal to D3S1263 and were informative for mapping the CHD gene. All three cases were deleted at
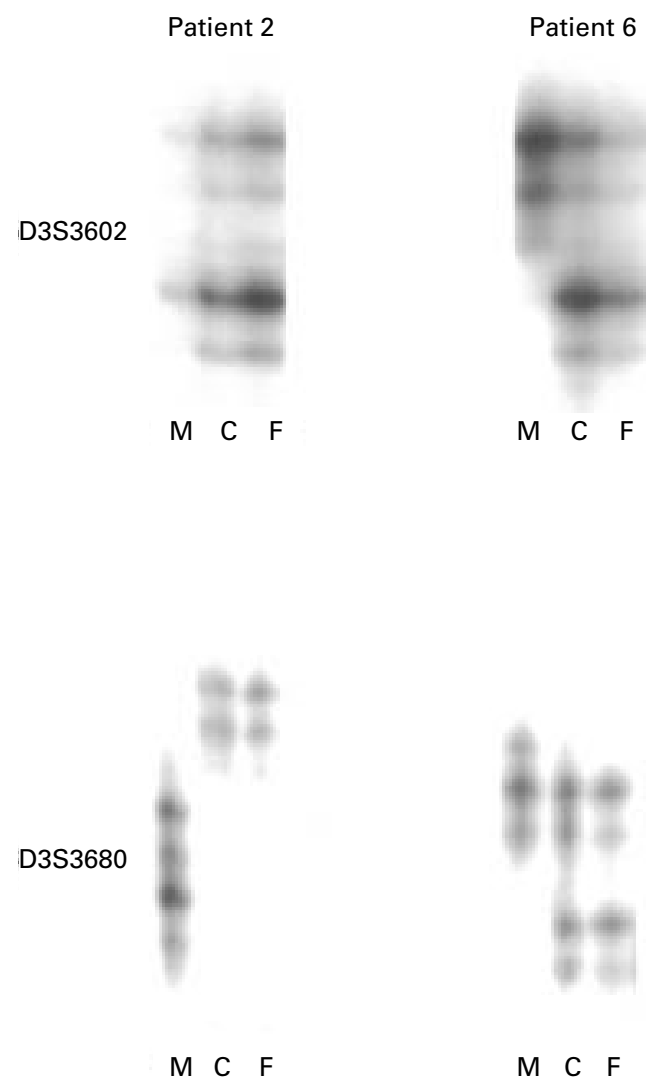

Figure 2 Polymorphic marker analysis of $3 p-$ syndrome patients. Results for D3S3602 and D3S3680 are shown for $P 2$ and P6. Both patients are heterozygous at D3S3602 and therefore not deleted for this marker. At D3S3680, P6 is also heterozygous, but $P 2$ shows failure to inherit a maternal allele. $M=$ mother, $C=$ child (proband), and $F=$ father. 
D3S3594. These results hence mapped the CHD gene to the D3S1263 to D3S3594 interval, assuming complete penetrance of $\mathrm{CHD}$, a distance of $3.7 \mathrm{cM}$.

PHYSICAL MAPPING OF 3p25 CHD SUSCEPTIBILITY LOCUS INTERVAL AND MAPPING OF CANDIDATE GENES

To facilitate (1) establishment of the correct mapping order, (2) estimates of physical distance, and (3) precise mapping of genes on $3 \mathrm{p} 25$, we isolated YAC and PAC clones from the region of interest. Five YACs were isolated (753F7, 949C12, 70D6, 52A10, and 736G10)

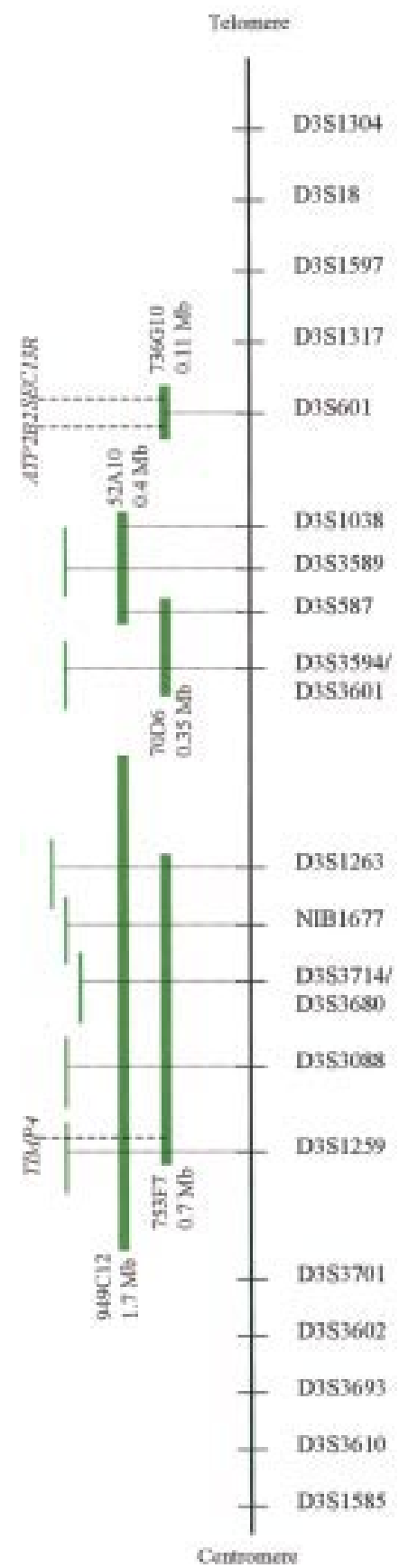

which contained markers from the region of interest as it was defined at the beginning of this investigation (fig 3 ). In all seven patients, YACs $70 D 6$ and 52A10 were deleted by FISH analysis. Multiple attempts to complete a YAC contig between YACs 949C12 and 70D6 were unsuccessful. This suggests that the interval between these two YACs may contain repeat sequences, as YACs spanning this region are unstable, and contain interstitial deletions or are chimeric.

Genes on chromosome 3p25 were precisely mapped by PCR amplification of the YACs and

Figure 3 YAC and PAC physical map of the 3p25 CHD critical interval. Chromosome 3p25-26 is represented by a horizontal line. YAC and PAC clones are positioned to the side and the marker content of each clone is indicated by dashed horizontal lines. The critical interval for the heart developmental gene is D3S1263 to D3S3594. Genetic distances between markers are shown below:D3S1585_1.6 cM_D3S3701_0.5 cM_D3S1259_0.5 cM_D3S1263_3.7 cM_D3S3594_2.6 cM_D3S1597_7.6 cM_D3S1304. 
PACs available using gene specific primers. TIMP4 mapped close to D3S1259 on PAC $248 \mathrm{M} 7$, centromeric to the critical interval. Genes $A T P 2 B 2$ and $\operatorname{Sec} 13 R$ were both positioned on YAC 736G10, distal to D3S3594, and so these two genes were also excluded. The fibulin 2 gene (FBLN2) was excluded as a candidate by typing a highly polymorphic dinucleotide repeat polymorphism and showing heterozygosity in $3 \mathrm{p}-$ patients with CHD (results not shown).

\section{Discussion}

In our previous analysis of $3 p-$ syndrome we suggested that a CHD susceptibility gene mapped to $3 \mathrm{p} 25 .{ }^{7}$ However, this analysis was based on only five cases and the mapping interval was very large (D3S1250 to D3S18). Subsequently, Drumheller et $a l^{11}$ investigated five $3 p-$ cases (four new cases), and also found that the only patient (GM10922 (P3)) with a $\mathrm{CHD}$ had the most extensive deletion. In doing so they refined the CHD target interval slightly to $\mathrm{D} 3 \mathrm{~S} 1585$ to $\mathrm{D} 3 \mathrm{~S} 1317$. In mapping the breakpoints of the seven patients with the largest deletions, we have provided further evidence for a CHD locus in 3 p 25 and significantly reduced the target interval. By assuming that the absence of CHD in patients P6 and P7 is not the result of non-penetrance, it is likely that haploinsufficiency of a gene or genes in the critical D3S1263 to D3S3594 interval disrupts cardiac development. Although incomplete penetrance has been described in familial AVSD, the mapping data in $3 p-$ syndrome patients is, so far, consistent with complete penetrance. However, a normal phenotype has been observed in patients even with large $3 p$ deletions, ${ }^{10}$ and if P6 or P7 are both nonpenetrant the candidate interval would extend more telomerically.

To evaluate candidate genes known to map to $3 \mathrm{p} 25$, we performed PCR amplification of the YACs and PACs with gene specific primers. In our previous studies ${ }^{7}$ and investigations by Drumheller et $a l,{ }^{11}$ the plasma membrane calcium transporter gene (ATP2B2) was contained within the target interval. However, by showing that it mapped distal to D3S3594, we were able to exclude $A T P 2 B 2$ as the CHD susceptibility locus. Similarly, the SEC13R gene ${ }^{16}$ was shown to map close to $A T P 2 B 2$ outside the critical CHD region. Another candidate gene from 3 p24-p25 is fibulin 2 (FBLN2), which is prominently expressed in mouse heart but present in low levels in other tissues. ${ }^{17-19}$ Nonetheless, we were able to show retention of FBLN2 in $3 \mathrm{p}-$ patients with CHD. The tissue inhibitor of metalloproteinases 4 (TIMP4) (which is highly expressed in the heart ${ }^{20}$ ) maps proximal to D3S1263 since it is situated on both YAC $949 \mathrm{C} 12$ and the PAC containing D3S1259. It too can therefore be excluded as a CHD susceptibility gene. Also excluded is the human caveolin-3 gene, suggested as a candidate 3 p25 CHD susceptibility gene but mapping close to D3S18, distal to the critical region. ${ }^{21}$ Recently a candidate extracellular matrix protein, cirrin, has been suggested as the CHD locus. However, detailed mapping data are not available for cirrin so it is not possible to exclude this gene. ${ }^{22}$

Although the primary objective of this study was to delineate the 3 p 25 CHD susceptibility region, our investigations have also refined the critical region for the major features of $3 p-$ syndrome. In previous studies of $3 p-$ syndrome, ${ }^{7911}$ the critical region for the $3 p-$ phenotype was mapped to the D3S601 to D3S17 interval $(21 \mathrm{cM})$. In the current study, analysis of P10 showed that D3S1317 was retained, so reducing the target region for the phenotypic features of $3 p-$ syndrome to the D3S1317 to D3S17 interval. D3S1317 lies in a $2 \mathrm{cM}$ interval between D3S601 and D3S18, with D3S17 lying a further $19 \mathrm{cM}$ telomeric to D3S18.

The parental origin of the chromosome $3 p$ deletion in the six informative cases studied by us was maternal. Combining our results with those of Mowrey et $a l,{ }^{9}$ the parent of origin of $3 \mathrm{p}$ deletions is maternal in six cases and paternal in two. Devriendt $e t a l^{8}$ found that all of four instances of del(8p) syndrome had a maternal origin, and a preponderance of maternally derived deletions has also been reported in 1 p36 deletion syndrome. ${ }^{23}$ This maternal excess is in contrast to deletions of distal $4 \mathrm{p}$ and $5 \mathrm{p}$ (Wolf-Hirschhorn and Pitt-RogersDanks syndromes and cri du chat syndrome respectively), in which $\sim 80 \%$ of de novo deletions arise in the paternal germline. ${ }^{24-26}$ It has been suggested in studies of $1 \mathrm{p} 36$ deletions that the predominance of maternally derived deletions versus those paternally derived may be apparent because the deletion preferentially occurs during maternal gametogenesis. It may, however, be possible that there is a survival bias owing to imprinted genes in the region. ${ }^{23}$ There is no evidence that the phenotypic variability of $3 p-$ syndrome patients is influenced by genomic imprinting effects, as we did not detect phenotypic differences between those $3 p-$ syndrome patients with maternally derived deletions and those of paternal origin.

The isolation of the $3 \mathrm{p} 25$ CHD susceptibility gene will provide further insights into the mechanisms of normal cardiac development and enable the genetic pathology of familial and isolated AVSDs to be investigated. The detailed mapping results and localisation of the CHD gene to a $3.7 \mathrm{cM}$ interval, already partially covered by a YAC, will facilitate the identification of the chromosome 3p25 AVSD susceptibility gene.

We thank the British Heart Foundation for financial support, and Igor Kuzmin, Michael Lerman, Michael Kuo, Anita Rauch, John Tolmie, Wayne Lam, Sara Dyer, Peter Simpson, and Albert Schinzel for their help with this project.

1 Burn J, Brennan P, Little J, Holloway S, Coffey R,
Somerville J, Dennis NR. Recurrence risks in offspring of
adults with major heart defects: results from first cohort of
British collaborative study. Lancet 1998;351:311-16.
2 Wilson L, Curtis A, Korenberg JR, Schipper RD, Allan L,
Chenevix-Trench G, Stephenson A, Goodship A, Burn J. A
large, dominant pedigree of atrioventricular septal defect
(AVSD): Exclusion from the Down Syndrome critical
region on chromosome 21. Am $\mathcal{F}$ Hum Genet 1993;53:
1262-8
3 Cousineau AJ, Lauer RM, Pierpont ME, Burns TL,
Ardinger RH, Patil SR, Sheffield VC. Linkage analysis of 
autosomal dominant atrioventricular canal defects: exclu-

sion of chromosome 21. Hum Genet 1994;93:103-8.
4 Sheffield VC, Pierpont ME, Nishimura D, Beck JS, Burns TL, Berg MA, Stone EM, Patil SR, Lauer RM. Identification of a complex congenital heart defect susceptibility locus by using DNA pooling and shared segment analysis. Hum Mol Genet 1997;6:117-21.

5 Marino B, Reale A, Giannotti A, Digilio MC, Dallapiccola B. Nonrandom association of atrioventricular canal and del(8p) syndrome. Am F Med Genet 1992;42:424-7.

6 Digilio MC, Marino B, Guccione P, Giannotti A, Mingarelli R, Dallapiccolo B. Deletion 8p syndrome. Am f Med Genet 1998;75:534-6.

7 Phipps ME, Latif F, Prowse A, Payne SJ, Dietz-Band J, Leversha M, Affara N, Moore AT, Tolmie J, Schinzel A, Lerman MI, Ferguson-Smith MA, Maher ER. Molecular genetic analysis of the 3p- syndrome. Hum Mol Genet 1994;3:903-8.

8 Devriendt K, Matthijs G, Van Dael R, Gewillig M, Eyskens B, Hjalgrim H, Dolmer B, McGaughran J, BrondumB, Hjalgrim H, Dolmer B, McGaughran J, BrondumNielsen K, Marynen P, Fryns JP, Vermeesch JR. Delinea-
tion of the critical deletion region for congenital heart tion of the critical deletion region for congenital heart
defects on chromosome $8 \mathrm{p} 23.1$. Am f Hum Genet 1999;64: defects on

9 Mowrey P, Chorney MJ, Venditti CP, Latif F, Modi WS, Lerman MI, Zbar B, Robins DB, Rogan PK, Ladda RL. Clinical and molecular analyses of deletion of 3p25-pter. Am F Med Genet 1993;46:623-9.

10 Knight LA, Yong MH, Tan M, Ng ISL. Del(3)(p25.3) without phenotypic effect. 7 Med Genet 1995;32:994-5.

11 Drumheller T, McGillivray BC, Behrner D, MacLeod P, McFadden DE, Roberson J, Venditti C, Chorney K, Chorney M, Smith DI. Precise localisation of 3p25 breakpoints in four patients with the 3p-syndrome. F Med Genet 1996; 33:842-7

12 Ioannou PA, de Jong PJ. Construction of bacterial artificial chromosome libraries using the modified P1 (PAC) system. In: Dracopoli et al, eds. Current protocols in human genetics. In: Dracopoli et al, eds. Current protocols in huma

13 Lui W, Piechocki M, Shridhar V, Lytes G, Song Z, Nakamura Y, Drabkin H, Vance J, Smith DI. The isolation of a yeast artifical chromsome (YAC) contig extending for 2 megabases in the vicinity of the von Hippel-Lindau 2 megabases in the vicinity of the von Hip
disease gene. Hum Mol Genet 1993;2:1177-82.

14 Collod G, Chu ML, Sasaki T, Coulon M, Timpl R, Renkart L, Weissenbach J, Jondeau G, Bourdarias JP, Junien C, Boileau C. Fibulin-2: genetic mapping and exclusion as a candidate gene in Marfan syndrome type 2. Eur F Hum Genet 1996;4:292-5.

15 Riley J, Butler R, Ogilvie D, Finniear R, Jenner D, Powell S, Anand R, Smith JC, Markham AF. A novel, rapid method for the isolation of terminal sequences from yeast artificial chromosome (YAC) clones. Nucleic Acids Res. 1990;18: 2887-90.

16 Swaroop A, Yang-Feng TL, Liu W, Gieser L, Barrow LL Chen KC, Agarwai N, Meisler MH, Smith DI. Molecular characterisation of a novel human gene SEC13R, related to the yeast secretory pathway gene SEC13, and mapping to a conserved linkage group on human chromosome 3p24-p25 and mouse chromosome 6. Hum Mol Genet 1994;3:1281-6.

17 Pan TC, Sasaki T, Zhang RZ, Fassler R, Timpl R, Chu ML. Structure and expression of fibulin-2, a novel extracellular matrix protein with multiple EGF-like repeats and consensus motifs for calcium binding. F Cell Biol 1993;123:126977.

18 Zhang RZ, Pan TC, Zhang ZY, Mattei M-G, Timpl R, Chu ML. Fibulin-2 (FBLN2): human cDNA sequence, mRNA expression, and mapping of the gene on human and mouse chromosomes. Genomics 1994;22:425-30.

19 Zhang HY, Chu ML, Pan TC, Sasaki T, Timpl R, Ekblom P. Extracellular matrix protein fibulin-2 is expressed in the embryonic endocardial cushion tissue and is a prominent component of valves in adult heart. Dev Biol 1995;167:18 26.

20 Olson TM, Hirohata S, Ye J, Leco K, Seldin M, Apte SS. Cloning of the human tissue inhibitor of metalloproteinase-4 gene (TIMP4) and localisation of the TIMP4 and Timp4 genes to human chromosome $3 \mathrm{p} 25$ and mouse chromosome 6, respectively. Genomics 1998;51:14851 .

21 Sotgia F, Minetti C, Lisanti MP. Localization of the human caveolin-3 gene to the D3S18/D3S4163/D3S4539 locus ( 3 225), in close proximity to the human oxytocin receptor gene. Identification of the caveolin-3 gene as a candidate for deletion in 3p-syndrome. FEBS Lett 1999;452:177-80.

22 Maslen CL, Rupp PA, Olson SB, Reifsteck CA, Thornburg KL, Glanville RW. Characterisation of cirrin, a new extracellular protein gene that is associated with endocardial cushion defects in 3p- syndrome. Am f Hum Genet 1999;65:A43.

23 Wu YO, Heilstedt HA, Bedell JA, May KA, Starkey DE, MCPherson JD, Shapria SK, Schaffer LG. Molecular refinement of the 1 p36 deletion syndrome reveals size diversity and preponderance of maternally derived deletions. Hum Mol Genet 1999;8:313-21.

24 Dallapiccola B, Mandich P, Bellone E, Selicorni A, Mokin V, Ajmar F, Novelli G. Parental origin of chromosome 4p deletion in Wolf-Hirschhorn syndrome. Am f Med Genet 1993;47:921-4

25 Church DM, Bengtsson U, Nielsen KV, Wasmuth JJ, Niebuhr E. Molecular definition of deletions of different segments of distal $5 p$ that result in distinct phenotypic features. Am f Hum Genet 1995;56:1162-72.

26 Kant SG, Van Haeringen A, Bakker E, Stec I, Donnai D, Mollevanger P, Beverstock GC, Lindeman-Kusse MC, Van Ommen GJ. Pitt-Rogers-Danks syndrome and WolfHirschhorn syndrome are caused by a deletion in the same region on chromosome 4p16.3. F Med Genet 1997;34:569- 